\title{
Views of the Hatchel Site (41BW3) During the 1938-1939 WPA Excavations
}

Timothy K. Perttula

Heritage Research Center, Stephen F. Austin State University

Follow this and additional works at: https://scholarworks.sfasu.edu/ita

Part of the American Material Culture Commons, Archaeological Anthropology Commons, Environmental Studies Commons, Other American Studies Commons, Other Arts and Humanities Commons, Other History of Art, Architecture, and Archaeology Commons, and the United States History Commons

Tell us how this article helped you.

This Article is brought to you for free and open access by the Center for Regional Heritage Research at SFA ScholarWorks. It has been accepted for inclusion in Index of Texas Archaeology: Open Access Gray Literature from the Lone Star State by an authorized editor of SFA ScholarWorks. For more information, please contact cdsscholarworks@sfasu.edu. 


\section{Views of the Hatchel Site (41BW3) During the 1938-1939 WPA Excavations \\ Creative Commons License \\ (c) $($ ) $(9)$}

This work is licensed under a Creative Commons Attribution-NonCommercial 4.0 International License 


\title{
VIEWS OF THE HATCHEL SITE (41BW3) DURING THE 1938-1939 WPA EXCAVATIONS
}

\author{
Timothy K. Perttula
}

The Hatchel site (41BW3) is a major prehistoric and protohistoric Caddo village and mound center on the Red River in Bowie County, Texas (Figure 1). The site was occupied by the Caddo from at least A.D. 1040 to the late $17^{\text {th }}$ century. The earliest end of this age range is based on 2-sigma calibrated ages from radiocarbon dates recently obtained in the village areas (Perttula 2003, 2005).

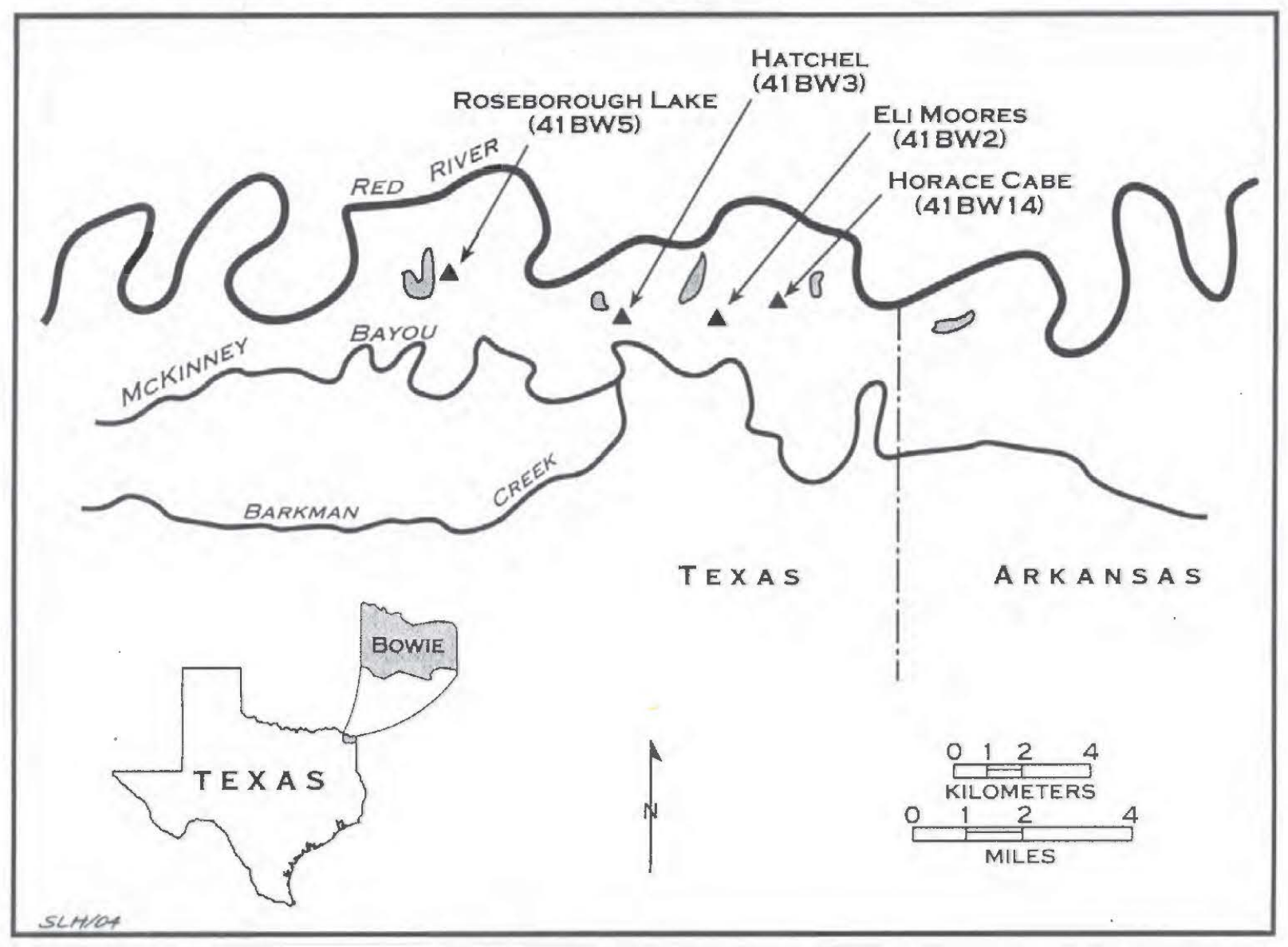

Figure 1. Hatchel site and other Late Caddo sites along the Red River in Bowie County, Texas.

In 1691, A Spanish expedition led by Don Domingo Teran de los Rios explored the Red River area (Hatcher 1999), and a detailed map was drawn of a Nasoni Caddo village that depicted a templo or temple mound at the western end of the village (Figure 2). That mound has been identified as the large earthen mound at the Hatchel site (see Wedel 1978). The map also showed many houses, and associated outbuildings, from numerous individual compounds in the village (Figure 3). The village itself is believed to have extended several miles along the Red River. 


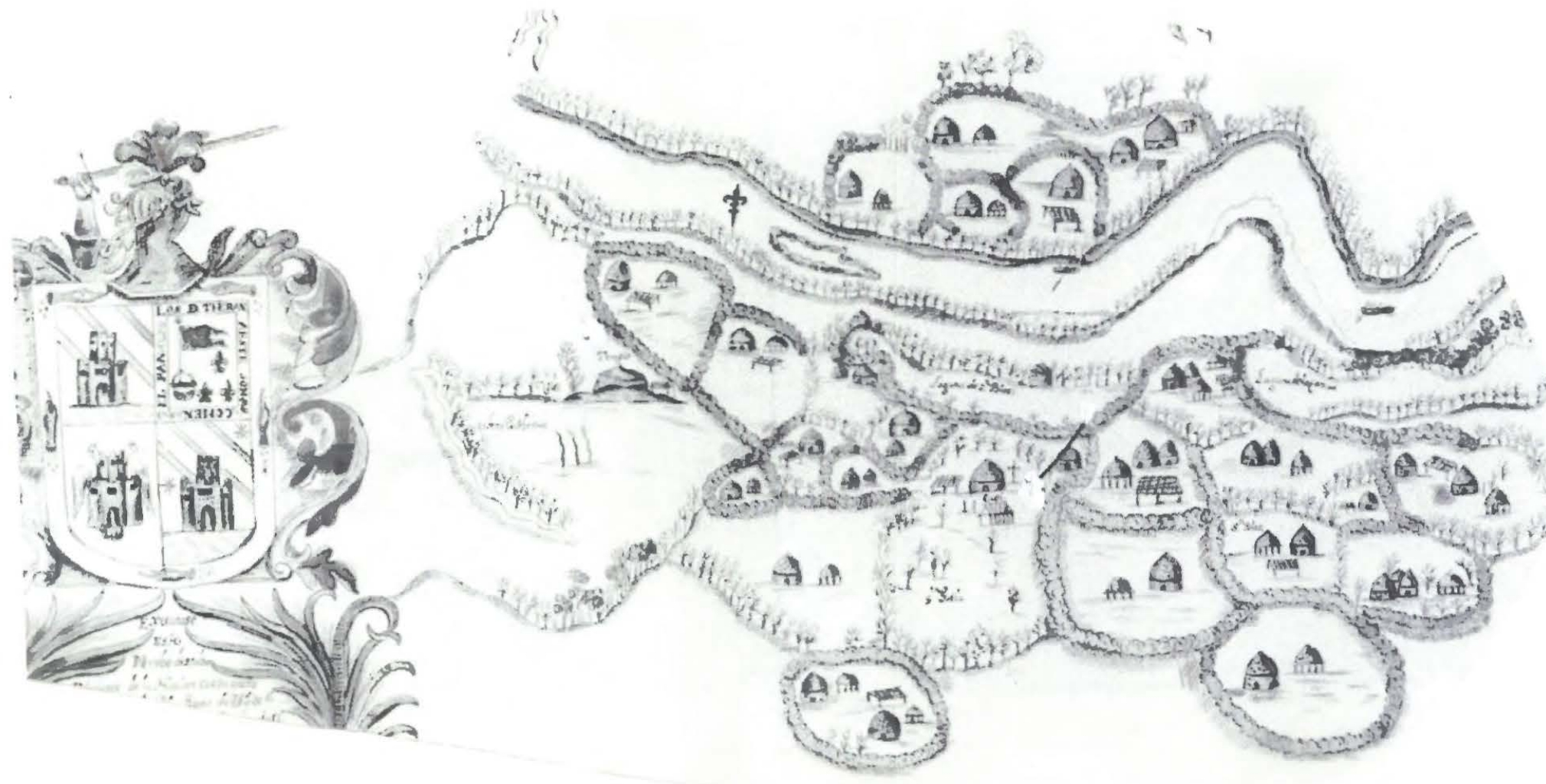

Figure 2. 1691 Teran Map.

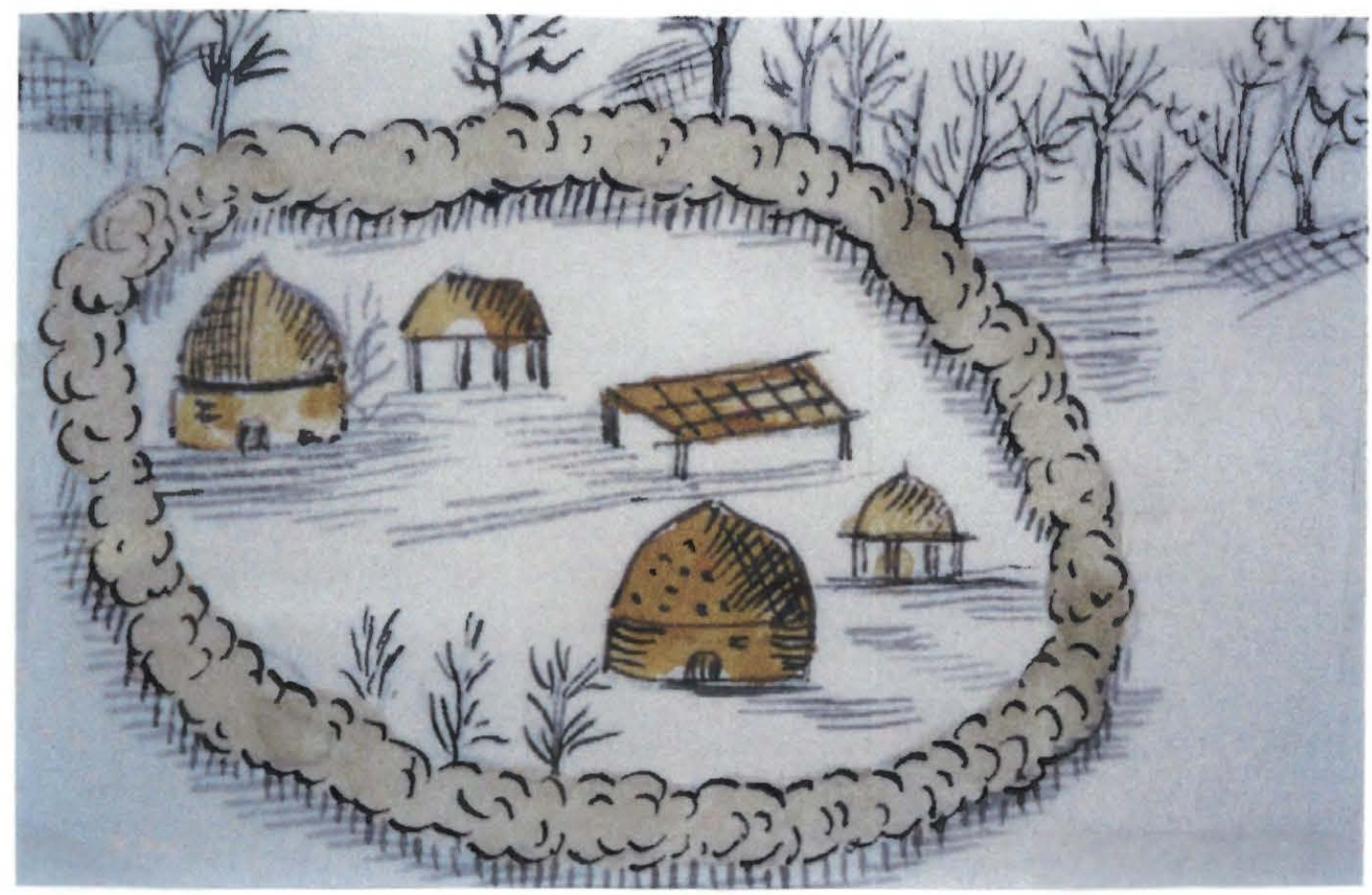

Figure 3. Close-up of Caddo house compound on the Teran map. 
We know that the Hatchel site contains extensive village archaeological deposits to the south, southeast, and southwest of the main earthen mound (Figure 4; see Perttula and Nelson 2003). The mound stood at least $25 \mathrm{ft}$. in height at the time of the Works Progress Administration (WPA) work (Figure 5). A second, and lower mound (Md. 2), stood about $3000 \mathrm{ft}$. southeast of the Hatchel Mound, in a cultivated field (Figure 6) some distance east of Village Area IV (see Figure 4).

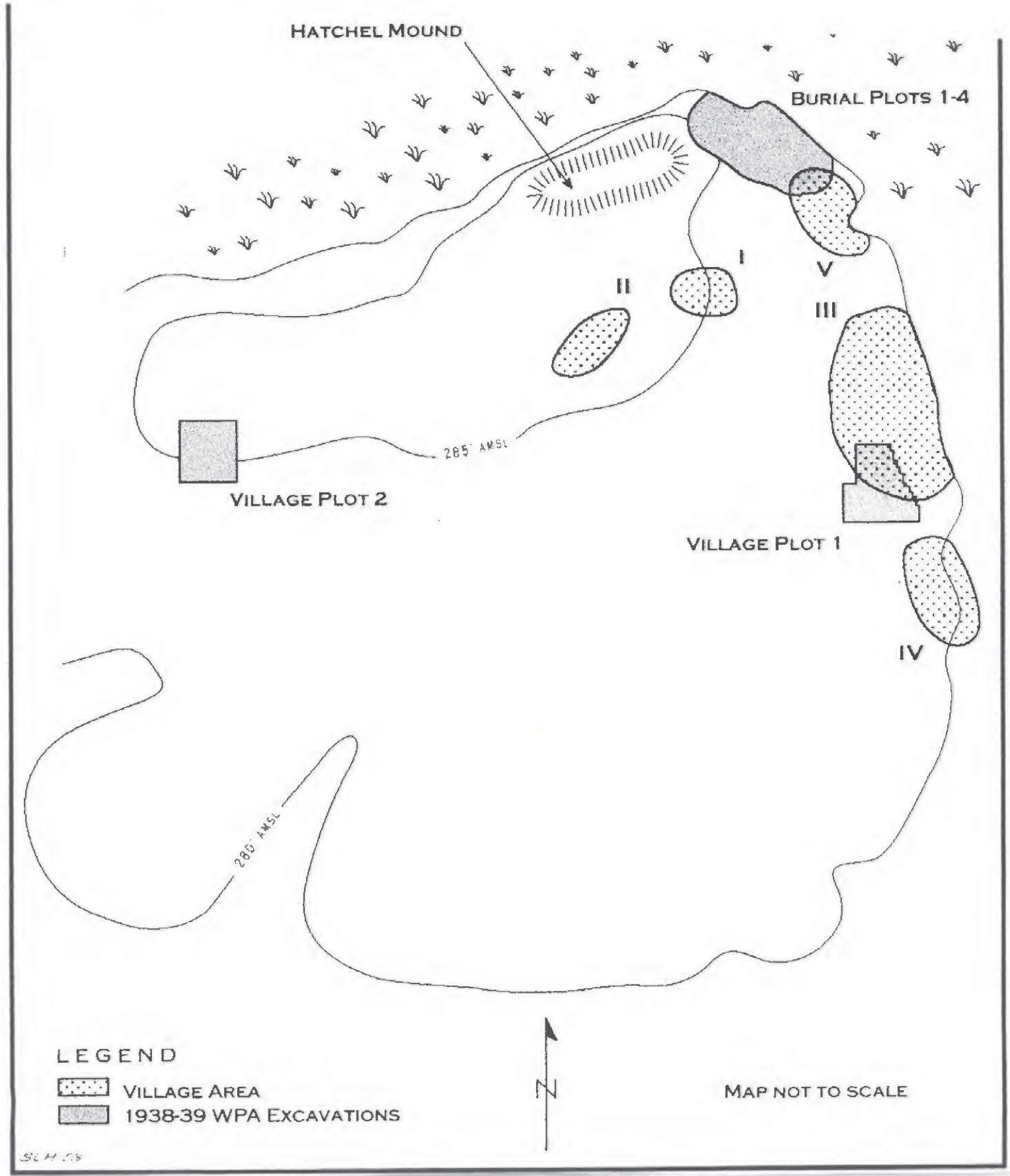

Figure 4. Village Areas I-V, the Hatchel Mound, and WPA excavations: Village Plots 1-2 and Burial Plots 1-4. 
Figure 5. Looking southwest at main earthen mound at the Hatchel site. 1ARL negative no. 41BW3-"

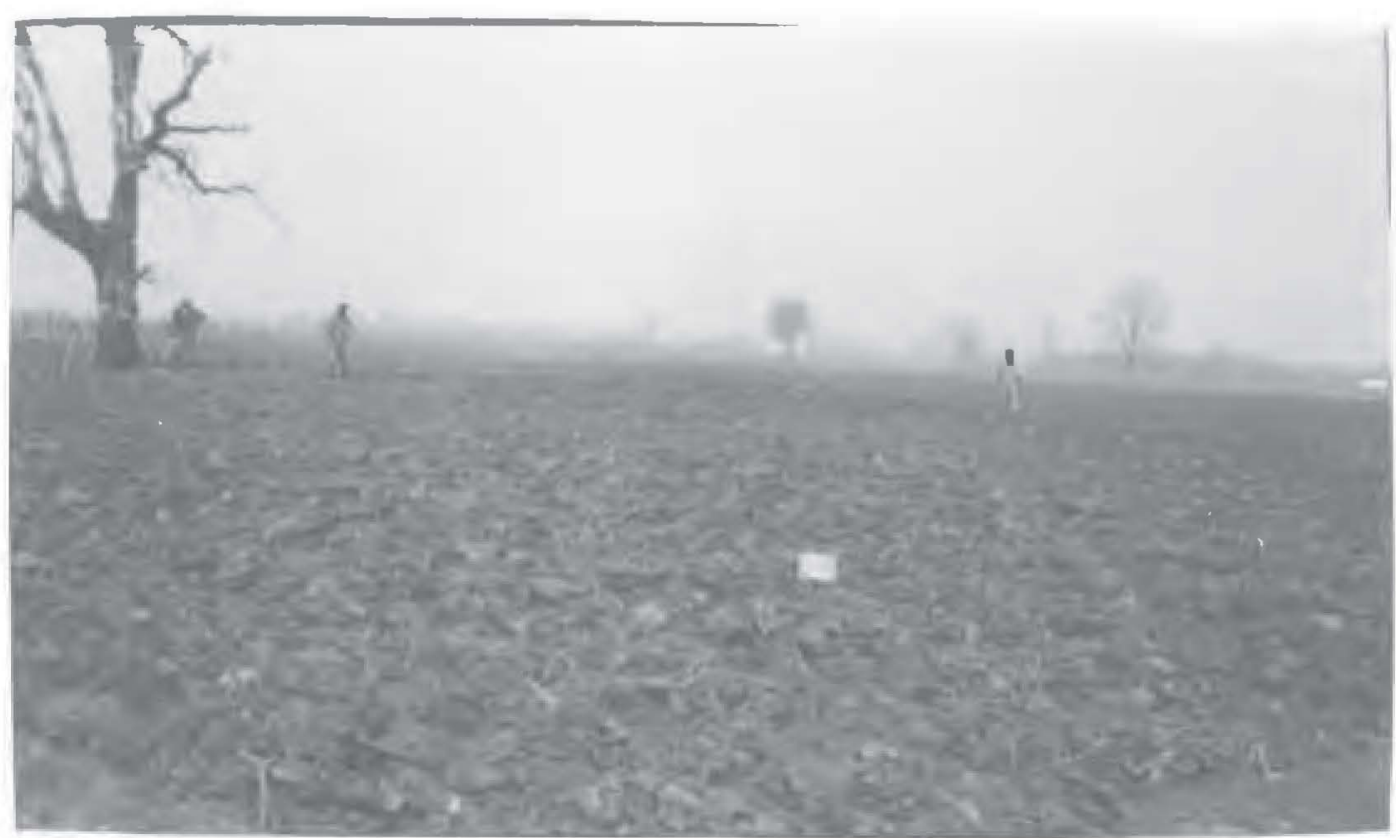

Figure 6. Md. 2 before WPA excavations were underway. TARL negative no. 41BW3149. 
The 1938-1939 WPA archaeological work was extensive, particularly in the main earthen mound (Figure 7). Here, multiple "floors" or mound surfaces with house structures were recognized in the mound (Jackson 2003, 2004). These all apparently date to the Late Caddoan period Texarkana phase occupation (ca. A.D. 1400-1600+). The mound covered a large structure on floor K, and a Crockett Curvilinear Incised vessel was found associated with this structure. The floor $\mathrm{K}$ structure was occupied sometime prior to ca. A.D. 1300. Village Area Il (see Figure 4), not far south of the main earthen mound, has three calibrated radiocarbon dates on occupational debris that range from A.D. 1040-128n 'Porttutia and Nelson 2003: Table 15).

Figure 7. Camera tow $r$ on Hatchel Mound; village ar : wie south. TARL negative no. $41 \mathrm{BW} 3-44$.

During the WPA excavations by the University of Texas, large-scale archaeological investigations also took place in the Hatchel site village (TARL n.d.). These include Village Plot 1 and 2 and Burial Plots $1-4$ (see Figure 4). The village at Hatchel seems to have been composed of a number of distinct village areas. It is likely that these areas represent different individual compounds or sets of related compounds (see Figure 3) of Caddo families and/or extended families that contained grass-covered house structures, above-ground granaries, and outdoor ramadas or arbors.

Village Plot 1 was in the same general location as Village Area III defined by 
Perttula and Nelson (2003) (see Figure 4), in a large cultivated field south of the Hatchel Mound (Figure 8). The WPA work was done by laborers and tenant farmers that lived in the local area (Figure 9). The block excavations in Village Plot 1 (Figure 10) contained numerous post holes (Figures 11-12), along with several structures (Figure 13, see also Figure 12), pits, and a midden deposit from a Texarkana phase occupation.

Figure 8. The Hatchel site, with the large earthen mound in the distance and village areas in the foreground. TARL negative no. 41BW3-125.

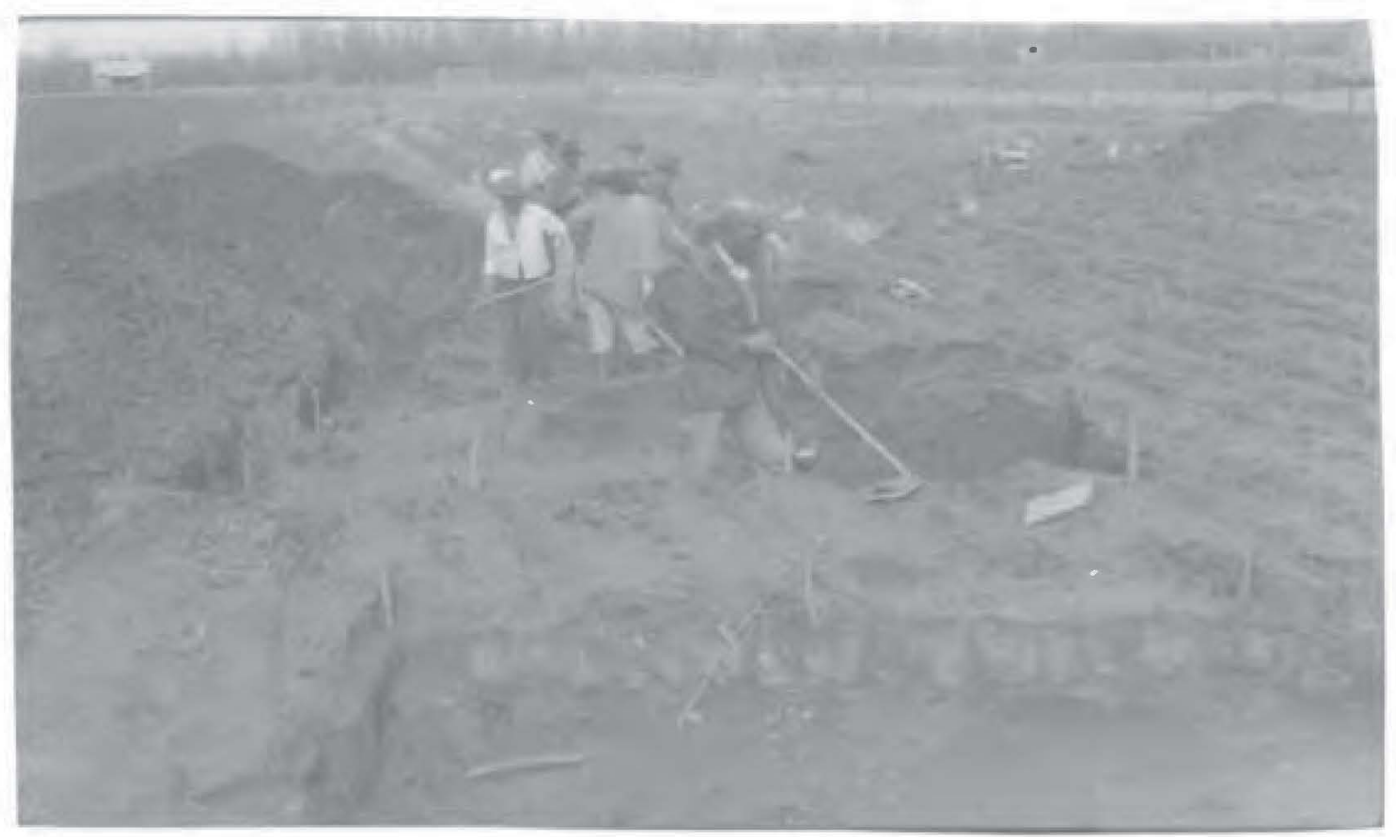

Figure 9. Beginning excavations in Village Plot 1. TARL negative no. 41BW3-57. 


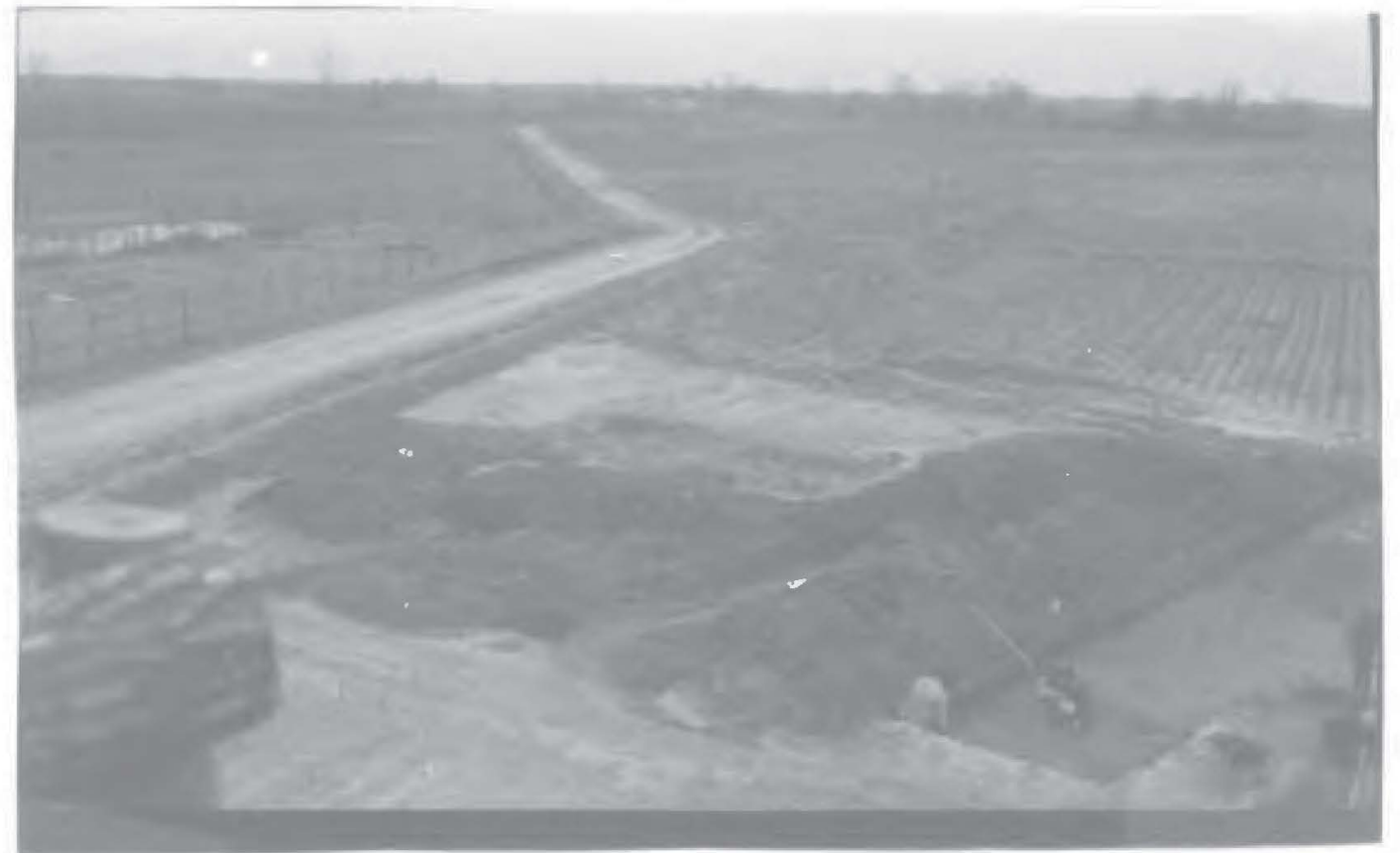

Figure 10. Village Plot 1 excavations, looking south. TARL negative no. 41BW3-126.

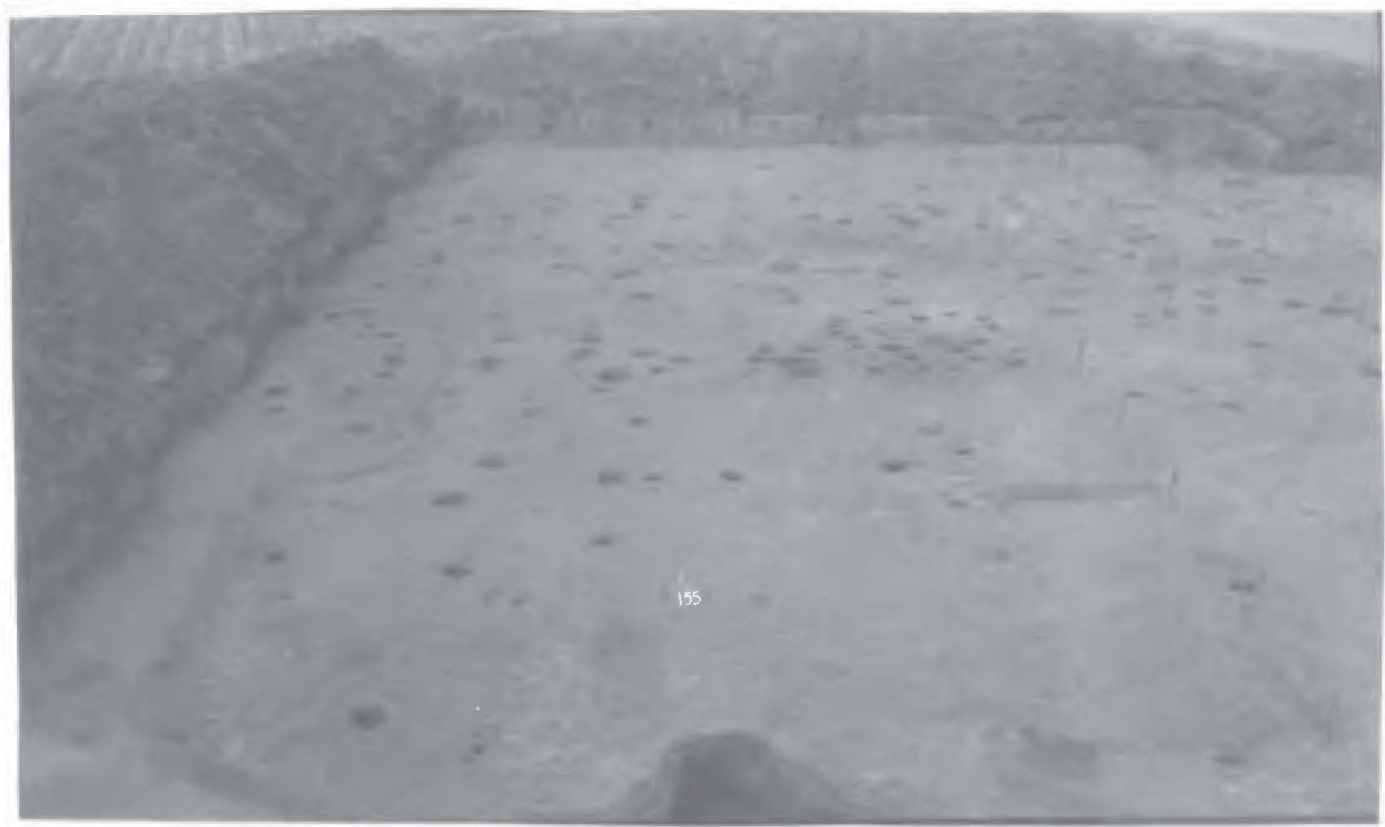

Figure 11. Excavations completed in western half of $1^{\text {st }}$ excavated section, Village Plot 1; note Fea. 2 in left center of photograph. TARL negative no. 41BW3-77. 


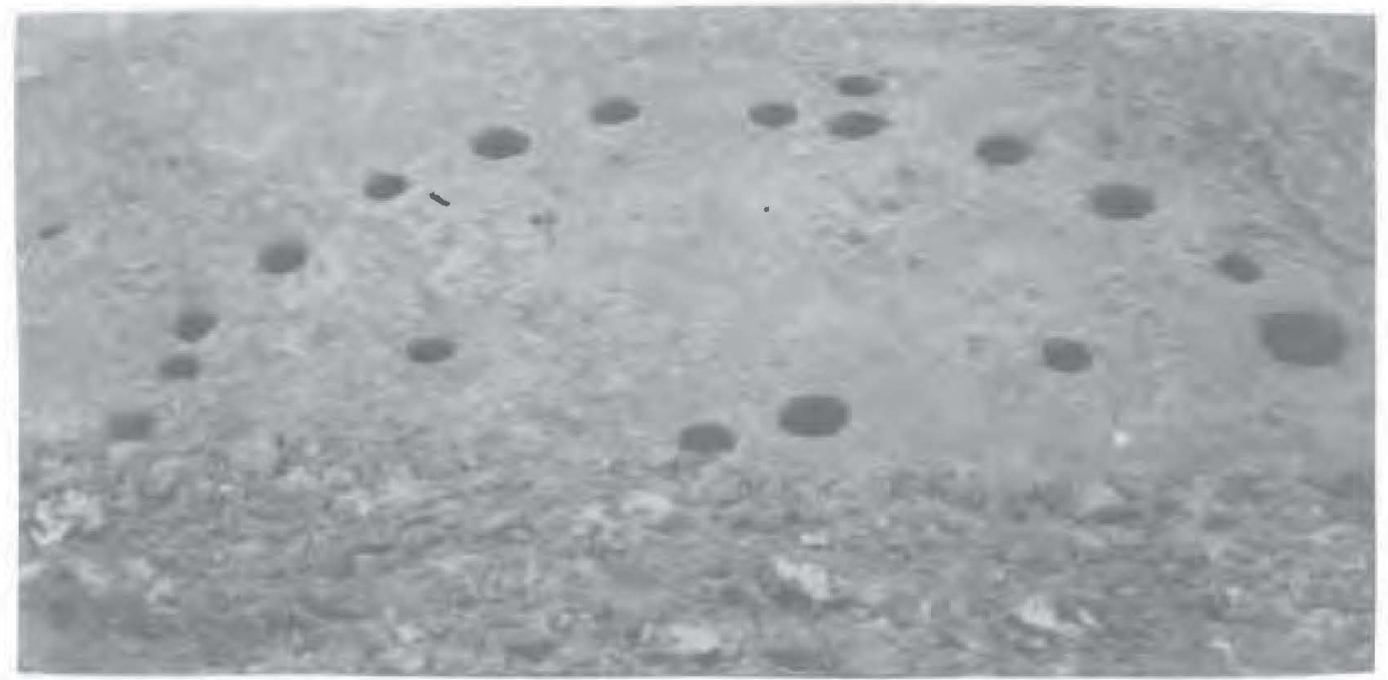

Figure 12. Looking west at Fea. 2 post holes. TARL negative no. 41BW3-141.

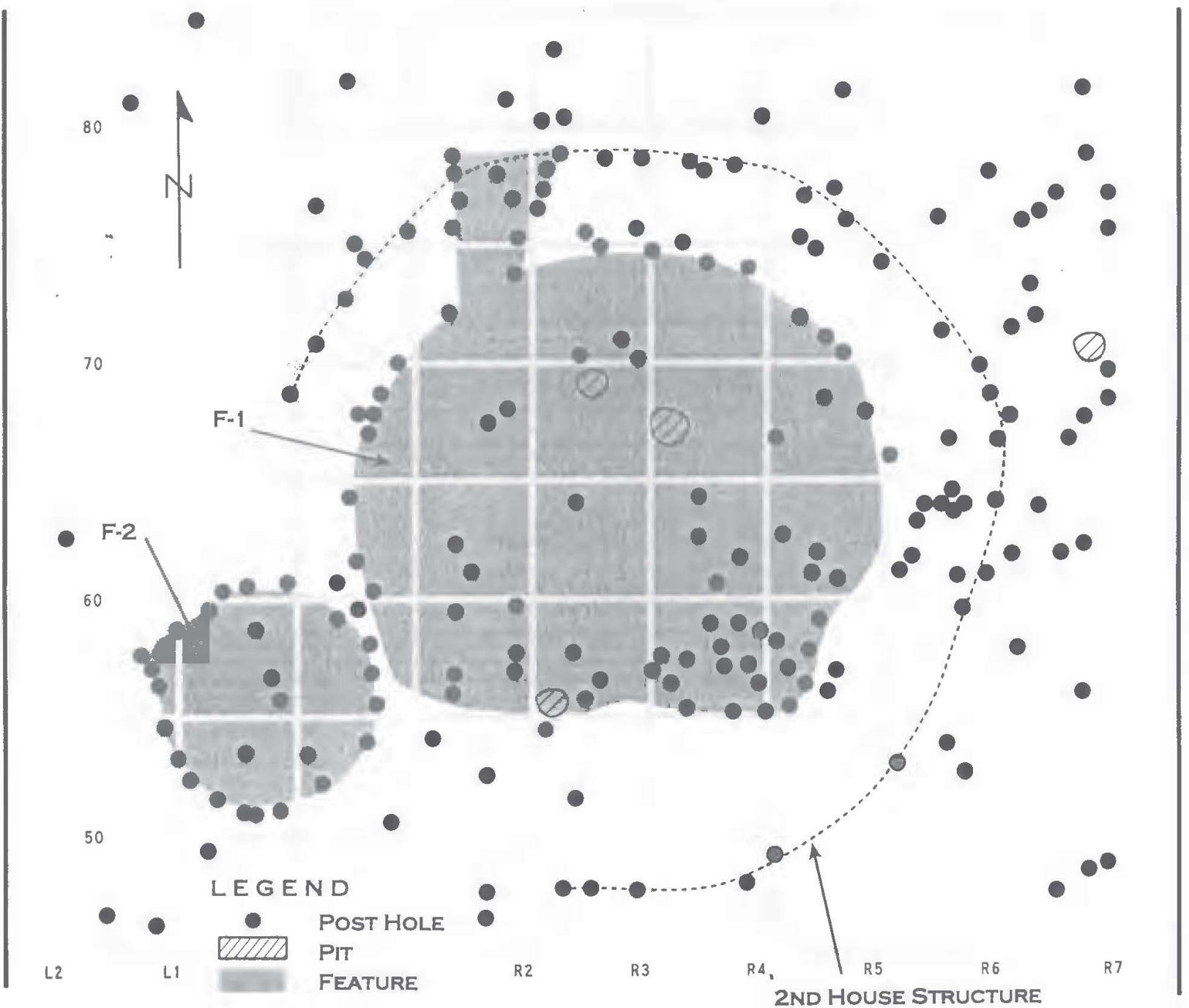

Figure 13. Features and post holes in Village Plot 1. 
WPA Village Plot 2 lay some distance to the southwest of the main earthen mound, but was also in a cultivated field (Figure 14). The block excavations here exposed portions of several structures, part of a possible compound fence (Figure 15), and burials from a Texarkana phase cemetery (Figure 16).

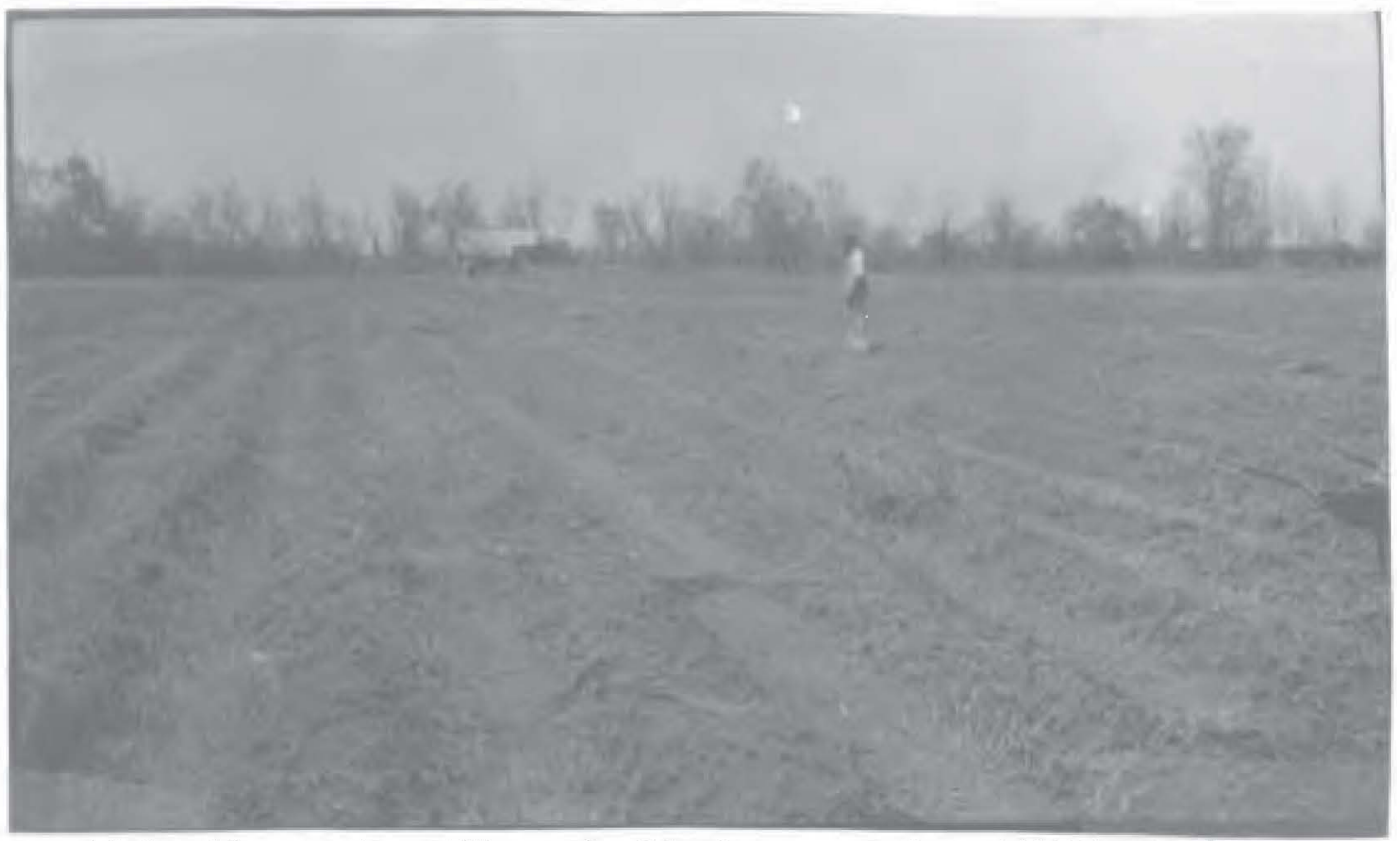

Figure 14. Looking north at Village Plot 2 before excavations. TARL negative no. 41BW3-177.

The WPA excavations at the Hatchel site have not been fully studied or the results published to date. Hopefully, renewed examination of the records and collections from the WPA archaeological investigations will be done, and will contribute to a fuller understanding of the history and prehistory of the Caddo peoples that lived at the Hatchel site and other villages in the Red River valley of northeastern Texas.

\section{ACKNOWLEDGMENTS}

I appreciate the permission of the Texas Archeological Research Laboratory at The University of Texas at Austin to reproduce a number of the WPA photographs of the archaeological excavations at the Hatchel site. Sandra Hannum prepared several of the site maps and WPA block excavations used in this article. 
Journal of Northeast Texas Archaeology, No. 21 (2005)

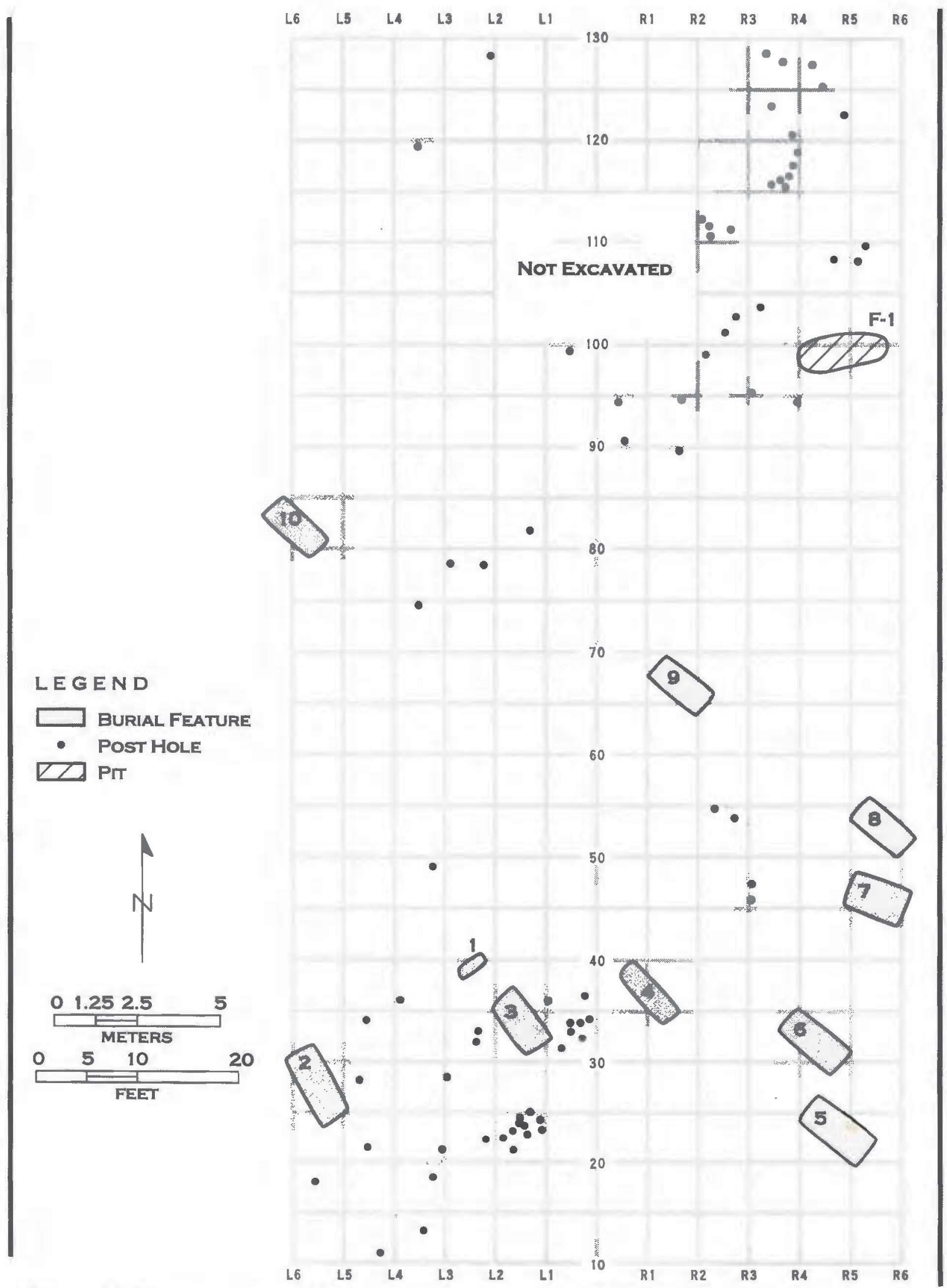

Figure 15. Features and post holes in Village Plot 2. Note burials 1-9. 


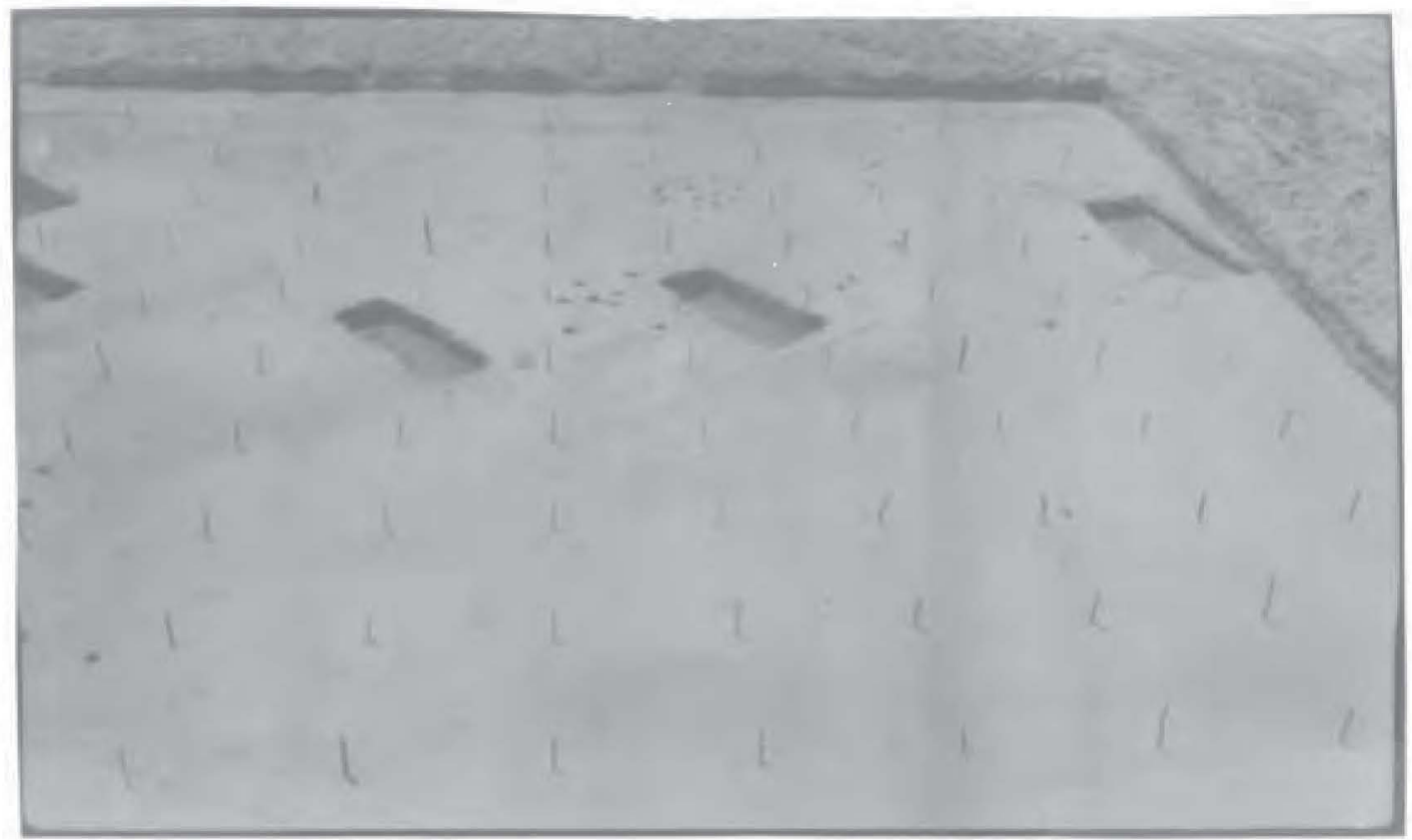

Figure 16. Village Plot 2, note the excavated burial pits. TARL negative no. 41BW3-201.

\section{REFERENCES CITED}

Hatcher, M. A.

1999 The Expedition of Don Domingo Teran de los Rios into Texas. In Wilderness Mission: Preliminary Studies of the Texas Catholic Historical Society, II, edited by J. F. de la Teja, pp. 1-66. Studies in Southwestern Catholic History No. 2. Texas Catholic Historical Society, Austin.

Jackson, A. T.

2003 Hatchel Site and Paul Mitchell Cemetery. Caddoan Archeology Journal 13 (No. 2):25-27.

2004 Excavation of an Earth Mound, Bowie County, Texas. Caddoan Archeology Journal 13 (No. 3/4):57-64.

Perttula, T. K.

2003 Archeological Investigations of Village Areas at the Hatchel Site (41BW3), Bowie County, Texas. Newsletter of the Friends of the Texas Archeological Research Laboratory, May 2003, pp. 2-8.

2005 1938-1939 WPA Excavations at the Hatchel Site (41BW3) on the Red River in Bowie County, Texas. Southeastern Archaeology, in press. 
Perttula, T. K. and B. Nelson

2003 Archeological Investigations of Village Areas at the Hatchel Site (41BW3), Bowie County, Texas. Report of Investigations No. 58. Archeological \& Environmental Consultants, LLC, Austin.

TARL

n.d. Binder NO. 5. ET-30 Village, Plots 1 and 2, and Mound No. 2, pp. 549-685. MS on file at the Texas Archeological Research Laboratory, The University of Texas at Austin.

Wedel, M. M.

1978 La Harpe's 1719 Post on Red River and Nearby Caddo Settlements. Bulletin 30. Texas Memorial Museum, Austin. 